\title{
Pandemi dan Pendidikan
}




\section{UU No. 28 Tahun 2014 tentang Hak Cipta}

\section{Fungsi dan Sifat Hak Cipta Pasal 4}

Hak Cipta sebagaimana dimaksud dalam Pasal 3 huruf a merupakan hak eksklusif yang terdiri atas hak moral dan hak ekonomi.

\section{Pembatasan Pelindungan Pasal 26}

Ketentuan sebagaimana dimaksud dalam Pasal 23, Pasal 24, dan Pasal 25 tidak berlaku terhadap:

i. penggunaan kutipan singkat Ciptaan dan/atau produk Hak Terkait untuk pelaporan peristiwa aktual yang ditujukan hanya untuk keperluan penyediaan informasi aktual;

ii. penggandaan Ciptaan dan/atau produk Hak Terkait hanya untuk kepentingan penelitian ilmu pengetahuan;

iii. Penggandaan Ciptaan dan/atau produk Hak Terkait hanya untuk keperluan pengajaran, kecuali pertunjukan dan ponogram yang telah dilakukan pengumuman sebagai bahan ajar; dan

iv. penggunaan untuk kepentingan pendidikan dan pengembangan ilmu pengetahuan yang memungkinkan suatu Ciptaan dan/atau produk Hak Terkait dapat digunakan tanpa izin Pelaku Pertunjukan, Produser Fonogram, atau Lembaga Penyiaran.

\section{Sanksi Pelanggaran Pasal 113}

1. Setiap orang yang dengan tanpa hak melakukan pelanggaran hak ekonomi sebagaimana dimaksud dalam Pasal 9 ayat (1) huruf i untuk Penggunaan Secara Komersial dipidana dengan pidana penjara paling lama 1 (satu) tahun dan/atau pidana denda paling banyak Rp100.000.000,00 (seratus juta rupiah).

2. Setiap orang yang dengan tanpa hak dan/atau tanpa izin Pencipta atau pemegang Hak Cipta melakukan pelanggaran hak ekonomi Pencipta sebagaimana dimaksud dalam Pasal 9 ayat (1) huruf c, huruf d, huruf f, dan/atau huruf h untuk Penggunaan Secara Komersial dipidana dengan pidana penjara paling lama 3 (tiga) tahun dan/atau pidana denda paling banyak Rp500.000.000,00 (lima ratus juta rupiah). 


\section{Pandemi dan Pendidikan}

Diky Pranondo, Sahria, Nartini,

Lina puspitasari, Azzahra Afita, Wirda Ina, Sri Yulia

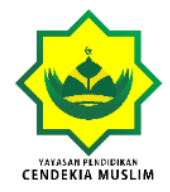


PANDEMI DAN PENDIDIKAN

Diky Pranondo, Sahria, Nartini, Lina Puspitasari, Azzahra Afita,

Wirda Ina, Sri Yulia.

Editor:

Ulfa Nur Halizah

Desainer:

Mifta Ardila

Sumber:

www.cendekiamuslim.com

Penata Letak:

Ulfa Nur Halizah

Proofreader:

TIM YPCM

Ukuran:

vii, 54 hlm., $14,8 \times 21 \mathrm{~cm}$

ISBN:

978-623-96391-8-1

Cetakan Pertama:

Maret 2021

Hak Cipta 2021, pada

Diky Pranondo, Sahria, Nartini,

Lina Puspitasari, Azzahra Afita,

Wirda Ina, Sri Yulia.

Isi di luar tanggung jawab penerbitan dan percetakan

Hak Cipta dilindungi undang-undang.

Dilarang keras menerjemahkan, memfotokopi, atau memperbanyak sebagian atau seluruh isi buku ini tanpa izin tertulis dari penerbit.

\section{YAYASAN PENDIDIKAN CENDEKIA MUSLIM PRESS}

Perumahan Gardena Maisa 2 C. 12, Koto Baru, Kecamatan Kubung,

Kabupaten Solok, Provinsi Sumatra Barat - Indonesia 27361

HP/WA: 0823-9205-6884

Website: www.cendekiamuslim.com

E-mail: cendekiamuslimpress@gmail.com 
Puji syukur kehadirat Allah Swt. yang senantiasa memberikan kesehatan dan hidayah-Nya sehingga semua penulis dapat menyelesaikan penulisan buku ini secara bersama.

Buku yang berjudul Pandemi dan Pendidikan ini berisi cerita-cerita pendek mengenai pandemi yang berdampak kepada pendidikan dan mengharuskan kita melek teknologi.

Harapan semua penulis dengan selesainya penulisan buku ini, bisa menjadi inspirasi bagi pembaca untuk tidak berhenti berharap meski banyak rintangan.

Penulisan buku ini dapat diselesaikan berkat bantuan dan dukungan dari berbagai pihak. Buku ini jauh dari sempurna karena kesempurnaan hanya milik Allah Swt. Dengan segala kekurangan buku ini, penulis mengharapkan saran dan kritikannya.

Solok, 2021

Tim Nulis Jamaah 


\section{DAFTAR ISI}

\section{PRAKATA}

V

DAFTAR ISI ..................................................... vii

1. Dampak Pandemi terhadap Negeri..............1

2. Belajar Era Pandemi 7

3. Kabut Pandemi di Usia Belia ......................15

4. Impact Pandemi terhadap Pendidikan dan Teknologi ....................................................25

5. Pandemi Oh Pandemi .................................29

6. Es Lilin dalam Tas Sekolah.........................35

7. Karirku Berlayar di Era Corona ..................45

TENTANG PENULIS .49 


\section{Dampak Pandemi terhadap Negeri}

Di era meningkatnya populasi manusia, dimana zaman yang semakin berkembang, dan teknologi yang semakin cangih. Semua terhenti dengan seketika, bagai bumi terhenti sejenak untuk berotasi, kelam seketika di kala datangnya Pandemi. Aku sadar akan akibat yang muncul terhadap negeri, dan akibatnya seluruh aktivitas akan terhenti sejenak, karena adanya tamu tak di undang datang tanpa permisi. Yah, namanya adalah Covid-19. Sedari awal semua orang mengetahui apa akibat dari datangnya pandemi ini, dan aku juga tahu aktivitas akan terhenti sejenak, roda perekonomian akan mengalami penurunan, dan negeri sepi bagai tak berpenghuni.

Entah siapa yang pantas untuk di salahkan, yang mengundang datangnya pandemi tanpa permisi ke negeri ini. Semua kalangan terkena dampak akibat datangnya pandemi, kelaparan dimana-mana, tingkat kesejahteraan masyarat akan menurun dan resiko kematian yang besar akibat terpaparnya virus ini. Sebenarnya ini bukan hanya masalah satu negeri, tapi ini masalah satu dunia untuk menghadapi masalah ini. Aku dan semua orang berharap penanganan dari pendemi ini akan cepat di tertangani, kebijakan yang di ciptakan bertujuan untuk memutus persebaran Covid-19. Entah apa yang menghambat kebijakan yang dibuat, seolah-olah pandemi ini bukanlah dampak besar bagi sebagian orang.

Seharusnya masalah ini ditangani secara cepat, tepat dan tegas oleh pemerintah. Satgas Covid-19 di bentuk, aku dan 
semua orang berharap bahwa ini merupakan langkah positif yang di ambil oleh pemerintah, akupun merasa lebih tenang di bandingkan sebelumnya. Hari berganti, bulan pun berganti, tapi entah apa yang menjadikan semua ini masih tetap terjadi, peningkatan pasien pun molonjak, kekurangan tenaga medis di setiap rumah sakit, silih berganti tenaga medis terpapar dan mengalami kematiaan, tempat pemakaman pun penuh, tempat karantina pasien pun tak tertampung lagi. Siapa kah yang salah ? entah pemerintah yang terlalu lamban dalam penegakan protokol kesehatan, atau masyarakat yang memang tak mematuhi protokol yang di buat.

Jelas ini masalah semua pihak, termasuk aku. Aku pun merasahkan adanya ketidak patuhan, dan kurangnya kepedulian orang-orang terhadap protokol kesehatan yang di buat. Entah bagaimana kita harus menyikapi semua ini. Satu visi dan misi harus tercipta, satu sudut pandang harus terbentuk, satu tujuan harus terjalan. Yah.. untuk mengakhiri pandemi ini. Semua itu terucap dan tersiar di pamplet-pamplet jalan, surat kabar, bahkan iklan di media masa lainnya. Aku rasa itu merupakan langkah awal yang baik, supaya ada pengingat terhadap pentingnya kesehatan dikala pandemi seperti sekarang ini.

Berbicara mengenai dampak, tak lupa juga dampak yang paling mencolok dari pandemi ini terutama pada pelajar dan juga mahasiswa. Akupun sebagai mahasiswa pastinya sangat merasakan dampak tersebut secara langsung. Dikarenakan adanya pandemi virus corona atau Covid-19, Indonesia akhirnya menerapkan sistem bekerja dari rumah,

\section{I P a n d e m i d a n P e nd i d i ka n}


belajar dari rumah dan beribadah dari rumah. Seluruh kegiatan dianjurkan untuk dilakukan di rumah saja, karena virus ini dengan cepat dapat menginfeksi banyak orang dan dapat menyebabkan kematian, begitu juga dengan kegiatan belajar mengajar, mulai dari siswa maupun kalangan mahasiswa dianjurkan untuk belajar dari rumah dan tugas di berikan oleh guru-guru melalui daring.

Sudah banyak tugas yang diberikan, dan aku mengerjakan satu persatu kemudian mengumpulkannya. Walaupun diberi waktu untuk mengumpulkan, tetap saja tugas yang aku terima masih menumpuk karena terlalu sering menunda untuk mengerjakannya. Setelah selesai mengerjakan, sudah ada tugas baru lagi yang diberikan, dan itu membuat ku agak sedikit stres dengan keadaan ini. Ditambah lagi aku dituntut dengan cepat dan sigap harus paham akan jenis teknologi pembelajaran yang diberikan. Huuftt... sementara tugas sudah menunggu untuk dikirim tetapi aku masih aja kadang belum paham teknologi pembelajaran yang diberikan ini bagaimana.

Tugas yang diberikan ada yang melalui aplikasi belajar dan ada juga yang melalui media lainnya. Apabila tidak bisa mengerjakannya, atau aku belum mengerti, aku biasanya melihat beberapa sumber pembelajaran, buku ataupun media masa pembelajaran lainnya. Tetapi jika kita paham mengenai tugas yang telah di berikan, itu dapat memudahkan kita dalam mengerjakannya. Terkadang tugas yang diberikan itu dapat berbeda dari apa yang telah dijelaskan, jadi kita lebih di tuntut untuk lebih rajin lagi dalam mempelajari suatu materi baik dari 
penjelasan dosen maupun dan referensi lainnya, suka tidak suka saya sebagai mahasiswa harus siap dengan perubahan zaman seperti sekarang yang harus melek akan teknologi, dan mempelajari terus teknologi yang sedang berkembang. Memang Belajar di rumah juga ada kelebihanya tersendiri karena dengan kita belajar di rumah kita juga dapat berkumpul dengan keluarga. Dikarenakan virus ini aku dan keluarga jadi sering menghabiskan waktu bersama. Banyak orang yang mengeluh karena sekolah online dikarenakan banyaknya tugas yang diberikan dan waktu yang dikumpulkan terlalu cepat. Setiap hari selalu ada tugas baru yang diberikan dan saya biasanya tidak langsung mengerjakannya karena saya masih mengerjakan tugas yang sebelumnya. Jika semua tugas ku sudah selesai, biasanya aku membiasakan rutinitas untuk berolahraga untuk menjaga kesehatan di kala masa pandemi seperti sekarang ini, meningkatkan imun tubuh dan menghindari kemungkinan besar untuk terpapar virus. Hari Raya tahun ini juga di rumah saja, saudara dan sanak yang di luar kota juga tidak dapat pulang ke kampung halaman karena kondisi sekarang, karena takutnya membawa virus saat di perjalanan. Belajar dari rumah kadang membuat saya bosan, saya merindukan teman-teman, tetapi keadaan sangat tidak memungkinkan. Saya harap keadaan cepat pulih dan kembali seperti semula.

Beberapa bulan kemudian, aku pun mendapat suatu informasi bahwasa nya beberapa kampus sudah memperbolehkan kuliah tatap muka walaupun hanya untuk mata kuliah praktek saja. Tetapi dilakukannya dengan protokol kesehatan yang telah ditetapkan pemerintah tentunya. 
Dikarenakan sistem daring ini dinilai kurang efektif"karena tata cara belajar yang kurang membantu dalam pemahaman dari mahasiswa. Cara demi cara pun telah dilakukan oleh pemerintah dalam menanggulangi permasalahan Covid-19 ini , têtapi kasûs demi kasus pun masih terdengar lewat telinga ini. Jadi dapat kita simpulkan tidak satu pun suatu hal dapat kita atasi sendiri, salah satunya permasalahan Covid-19 ini. Kita tidak dapat hanya menyerahkan semuanya kepada pemerintah, tetapi kita pun juga harus saling membantu agar pandemi ini berakhir nantinya. Yang terpenting untuk kita semua, patuhi protokol kesehatan yang ada, jaga kebersihan lingkungan, dan selalu jaga kesehatan tubuh untuk menghindari terpaparnya Covid-19 ini. 


\section{Belajar Era Pandemi}

Gara-gara pandemi covid-19, pendidikan harus daring. Siti harus berpisah dengan teman-teman sekelasnya karena aturan protokol kesehatan pemerintah, jaga jarak minimal 2 meter, sering mencuci tangan pakai sabun, menggunakan masker, dan berbudaya hidup sehat.Yang paling berat bagi Siti adalah menjalani daring, biasanya Siti teratur belajar, pukul 06.30 sudah berangkat ke sekolah, menjalani aktivitas di sekolah dengan ceria dan semangat hingga waktu pulang pukul 15.00. Sepulang dari sekolah pekerjaan rumah sudah menanti. Menjaga adiknya yang masih bayi atau keliling kampung menjajakan makanan kecil olahan emak. Lelah dan berat beban pekerjaan rumah yang menggunakan tenaga otot. Struktur tubuh Siti yang kecil kerempeng bak gadis kurang gizi menyebabkan cepat lelah dengan beban kerja di rumah tersebut karena itulah sekolah bagi Siti terasa nikmat.

Gara-gara pandemi, pola-pola yang sudah teratur menjadi berubah. Banyak aplikasinya baru di pembelajaran. Awal pandemi pembelajaran mengoptimalkan WhatsApp (WA), bagi Siti tidak masalah dan masih dapat mengikuti. Beberapa bulan aplikasi di sekolah Siti menggunakan Google Classroom. Awalnya agak sulit belajar Google Classroom karena HP Siti kurang support alias jadul. Untung ada tabungan yang dapat digunakan untuk membeli HP yang dengan ram dan memory internal cukup. Itu bagi Siti tantangan juga karena harus belajar 
IT, yang sebelumnya tidak dipelajari. Dengan telaten, Siti belajar dan belajar agar pembelajaran daring tetap berjalan. Tetapi sebagian teman-teman Siti banyak yang kesulitan karena tidak tâhu harus menjawab dimana dan bagaimana. Hampir setiap ada tugas HP Siti ramai. Budi teman sekelasnya menulis, "Aduh, gara-gara daring uangku habis untuk beli pulsa ..." "lya, mendingan tatap muka ya... kita dapat uang jajan dari ortu." "Lha nanti tertular Covid-19 malah gawat," keluhnya. "Pulsaku cepat habis kalau begini terus, belum sinyalnya putus nyambung." "Aku juga bingung diajar secara daring". "Tapi ada Siti teman, dia kan baik hati. Kita minta dia yang ngerjakan trus jawabannya dikirim ke kita. Beresss...," hibur Rudi yang terkenal malas mengerjakan tugas. "Kasihan pulsa Siti dong jika harus ngirim jawaban ke kita semua", jawab yang lain. "Kita urunan untuk membelikan pulsa Siti". "Aduh, kalian ya harus mengerjakan sendiri dong...," balas Siti. "Jangan kawatir Siti, nanti kalau dapat uang saya ganti", hibur lainnya. Itulah celotehan teman-teman Siti. Memang pembelajaran berbeda, ada sebagian siswa yang membentuk kelompok belajar untuk mengerjakan tugas, dengan tetap mematuhi protokol kesehatan, ada yang berdiskusi lewat daring, dan ada yang setipe Rudi dan beberapa siswa yang menggantungkan tugas pada temannya. "Emakku juga sering marah, gara-gara setiap hari pegang HP, sehingga adikku jarang kugendong dan juga dagangan emak harus habis,"keluh Siti . Itulah kehidupan orang kecil. Suasana pandemi memang mengancam semua segi kehidupan. Ekonomi pun sulit. Banyak masyarakat berjaga diri dalam membeli jajanan karena takut ketularan Covid-19. Sementara untuk pembelajaran daring membutuhkan kuota 


\section{Profill Penulis}

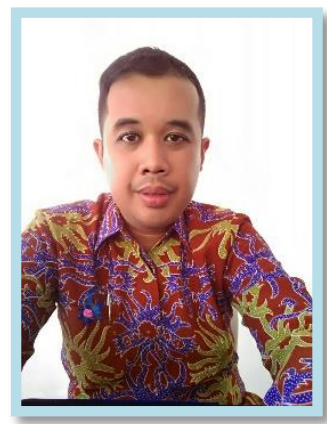

Diky Pranondo, lahir di koța empekempek-Palembang pada tanggal 9 September 1984 menyelesaikan pendidikan Sarjana tahun 2009 di jurusan Teknik Perminyakan UPN "Veteran" Yogyakarta. Penulis sendiri sangat tertarik dengan dunia IT dan Pendidikan. Saat ini juga aktif dalam pengembangan bisnis startup khususnya di bidang energi. Penulis mengajar di kampus Politeknik Akamigas Palembang. Mata kuliah yang Penulis ampuh antara lain: pengantar industri hulu migas, mekanika reservoar, metode pengangkatan buatan, teknik pemboran, ekonomi migas dan etika profesi.

SAHRIA, S.Pd Lahir di sebuah kota yang

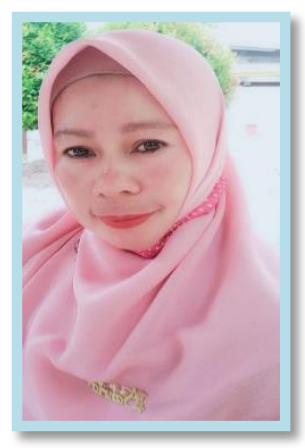
terkenal dengan sebutan Batutaneng Kecamatan Kahu Kabupaten BONE, yang tepat pada tanggal 01 Oktober 1976 dan menyelesaikan pendidikan dasar SD Inppre 12/79 Palakka dan menengah di kecamatan tempat kelahirannya SMPN1 Palattae. Melanjutkan sekolah Menengah di SMAN 9 Ujung Pandang yang sekarang lebih di kenal Kota Makasar tahun 1994. Di 
tahun yang sama melanjutkan di Institut Keguruan IImu Pendidikan IKIP ketika itu yang saat ini lebih di kenal sebutan Universitas Negeri Makasar ( UNM). la memilih Jurusan Seni Tari di Fakultas Pendidikan Bahasa dan Seni ( FPBS )ljazah Sarjana diperoleh penulis dijurusan Sendratasik IKIP Padang pada tahun 1999.

Setelah resmi menyandang gelar itu, ia memberanikan diri untuk hijrah ke Balikpapan mengabdi tahun 2000. Alhamdulillah tidak harus menunggu langsung di terima sebagai tenaga honorer/guru Kontrak di SMPN5 Penajam Paser Utara Kalimantan Timur. Tahun 2003 resmi sebagai CPNS di kota yang sama dan penempatan di sekolah yang sama sampai saat ini .

Pertama kali termotivasi menulis buku, setelah mengikuti workshop menulis Sagusaku satu guru satu buku di Penajam Paser Utara tahun 2018, dan Alhamdulillah bisa lounching sejumlah 38 maha karya bersama karya perdana yang berjudul Mihrab Cinta Bayu dan tercetak karya kedua tahun 2019. Ini karya yang ketigaku penulis sadar apa yang sudah di tulis terkesan jauh dari kesempurnaan. Harapan penulis semoga kedepannya dapat mencetak karya yang lebih sempurna.

Kritik dan saran di harapkan guna peningkatan dan kualitas pada penulisan selanjutnya Sahriariaoo@gmail.com 


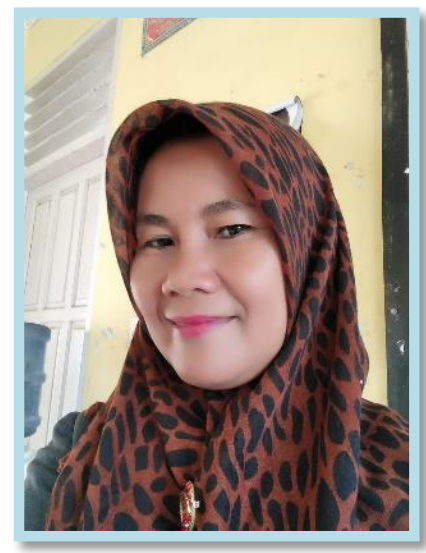

Hj. Wirda Ina lahir sébagai anak ketujuh dari delapan bersaudara, dengan izin Allah pada tanggal 14 Juni 1972 menangis pertama kâli didunia ini. Terlahir dari rahim seorang ibu yang luar biasa $\mathrm{Hj}$. Jawaris dan ayah yang gagah $\mathrm{H}$. Sawir (semoga keduanya mendapatkan tempat indah disisi Allah bersama hamba-hambaNya yang sholeh sholehah...aamiin).

Pindah tugas tahun 2012 ke kampung halaman, saat ini penulis aktif sebagai pengajar disalah satu sekolah menengah di kampung halaman tempat tinggal penulis setelah mengajar hampir 20 tahun di Ciamis Jawa Barat. Selain itu aktif sebagai IPHI kecamatan.

Penulis ikut berpartisipasi dalam menulis buku Antologi ini tergerak untuk menambah wawasan menulis, saling berbagi dengan penulis lain. Buku ini adalah yang ke empat setelah Buku Merdeka Dari Nestapa dan buku kedua Lisan Tak Bertuan serta buku ketiga Rekam Jejak Laku Cinta Bunda"Je".

Pindah tugas tahun 2012 ke kampung halaman, saat ini penulis aktif sebagai pengajar disalah satu sekolah menengah di kampung halaman tempat tinggal penulis setelah mengajar hampir 20 tahun di Ciamis Jawa Barat. Selain itu aktif sebagai IPHI kecamatan dan kegiatan sosial kemasyarakatan lainnya ditempat tinggal penulis. 


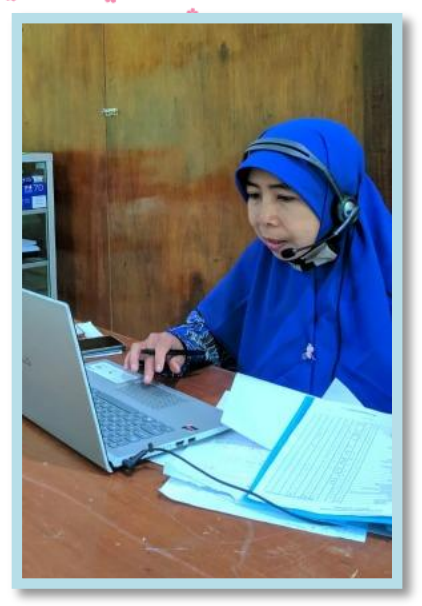

Nartini yang dilahirkan di Ngawi, sebuah kota kecil wilayah Jawa Timur pada tanggal 10 Mei 1974. Menyelesaikan pendidikan dasar di SD Jambangan 2, SMP di SMP Negeri 1 Ngawi tahun 1989 dan SMA Negeri 2 Ngawi tahun 1992. Ijazah SI diperoleh penulis dijurusan Pendidikan Matematika FKIP Universitas Sebelas Maret Surakarta pada tahun 1997. Sekarang penulis mengajar di SMP Negeri 1 Madiun mulai tahun 2020 setelah berlalu lalang di beberapa sekolah sebelumnya (SMPN 13 Madiun, SMPN 9 Madiun, SLB Siti Hajar, SMP N 1 Wungu).

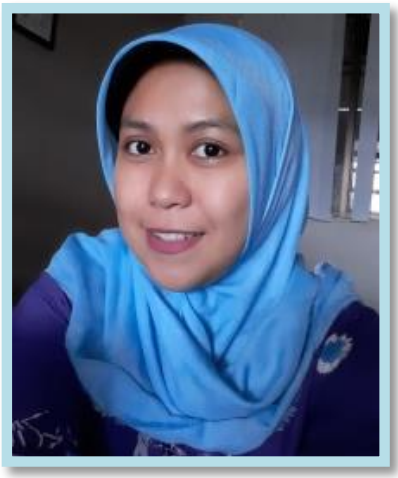

Lina puspitasari yang dilahirkan pada tanggal 26 Oktober 1990 di Kabupaten Cilacap. Jenjang pendidikan yang didapat antara lain SD, SMP dan SMA saya tempuh di kecamatan Majenang Kabupaten Cilacap. Kemudian saya melanjutkan pendidikan Diploma III Kebidanan di Kota Cilacap. Setelah itu ijazah Diploma IV Kebidanan Pendidik saya dapatkan 
di Poltekkes Kemenkes Surakarta dan terakhir, sayä menempuh Magister Ilmu Kesehatan Masyarakat di Universitas Sebelas Maret Surakarta dengan capaian ijazah tahun 2016.

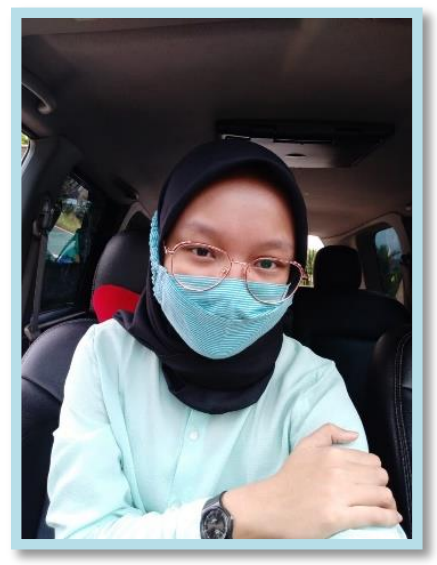

Azzahra Afita, siswa SMA yang dilahirkan di daerah istimewa Yogyakarta 16 tahun yang lalu. Menempuh pendidikan sekolah dasar hingga menengah pertama dikabupaten yang sama dan kecamatan yang sama, kini telah menempuh pendidikan di Sekolah Menengah Atas Negeri 2 Purwokerto yang merupakan SMA ranking pertama di Kabupaten Banyumas. Azzahra Afita menulis buku ini dengan tujuan untuk menggali bakat menulis. Setelah menempuh pendidikan di SMA ia ingin melanjutkan program studi kedokteran di Universitas Gadjah Mada impian nya itu, doakan ya teman-teman semoga cita-cita Azzahra dan teman-teman semua dapat tercapai, Aamiin... 


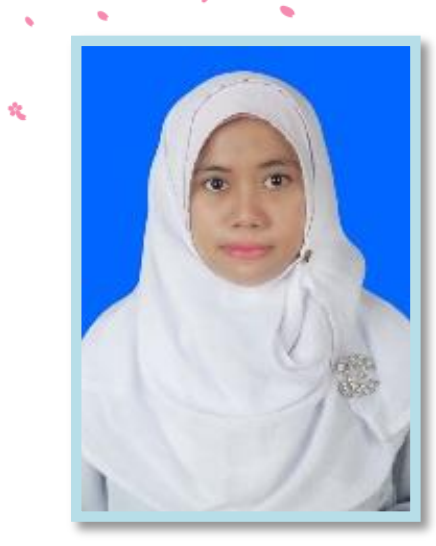

Sri Yulia yang dilahirkan di Saningbakar, Kecamatan $\mathrm{x}$ koto singkarak, Kabupaten solok pada tanggal 03 Juli 1993 menyelesaikan pendidikan dasar dan menengah di kecamatan tempat kelahirannya. Gelar kesarjanaan pada jurusan PAI di peroleh penulis di UMSB pada tahun 2015. Gelar Magister Pendidikan (M.Pd) jurusan PAI diperoleh di IAIN Bukittinggi pada tahun 2018. 